\title{
Water Development, Consumptive Water Uses, and the Great Salt Lake
}

\author{
${ }^{1}$ Sarah E. Null* and ${ }^{1}$ Wayne A. Wurtsbaugh \\ ${ }^{1}$ Department of Watershed Sciences, Utah State University, Logan, UT. 84322 \\ *Correspondence: Sarah E. Null (sarah.null@usu.edu)
}

\begin{abstract}
Utah's Great Salt Lake covers $5500 \mathrm{~km}^{2}\left(2100 \mathrm{mi}^{2}\right)$ at its unimpacted elevation and is the eighth largest saline lake in the world. Its highly productive food web supports millions of migratory birds and the economic value of the lake is estimate at $\$ 1.5$ billion in 2019 U.S. dollars. Droughts and wet cycles have caused huge fluctuations in lake level, area and salinities, and this variation has masked anthropogenic impacts. Recent work, however, has determined that consumptive water uses in the watershed have depleted inflows by approximately $39 \%$, with $63 \%$ used by agriculture, $11 \%$ by cities, $13 \%$ by solar ponds, and $13 \%$ by other uses. This has lowered the lake by $3.4 \mathrm{~m}$, decreased its area by $51 \%$, and reduced its volume by $64 \%$. Projected water development of the lake's primary tributary could lower the lake approximately $1.5 \mathrm{~m}$ more. Climate change, to date, has not noticeably influenced lake level. Per-capita water use in Utah is the second highest in the nation and is 2.6-fold higher than other semi-arid nations. Potential solutions exist to reduce consumptive water uses and stabilize or increase Great Salt Lake water level. Water conservation is likely the most economical solution, with permanently mandated water cutbacks costing $\$ 14-96$ million ( $\$ 5$ to $\$ 32$ per person). Water conservation paired with water markets reduce costs further, costing between $\$ 2$ to $\$ 16$ per person. Descriptions of potential solutions to reduce consumptive water uses and stabilize Great Salt lake level are a starting point to encourage discussion. Strategies have yet to be prioritized or thoroughly evaluated. Quantifying water diversions from rivers that feed Great Salt Lake and consumptive water uses will allow Utahns to make defensible decisions to manage water resources and the lake's biology for long term ecological, recreational, and economic benefit.
\end{abstract}

Keywords: Great Salt Lake; water level; lake elevation; depletion; terminal lake; salinity; Utah

\section{$1 \quad$ Introduction}

Utah's Great Salt Lake is the eighth largest terminal lake in the world and is one of Utah's most recognizable features. It supports a highly productive food web with microbial mats, phytoplankton, and macroinvertebrates (Belovsky et al., 2011; Pace et al., 2016), provides wetland habitat for millions of migratory birds (Aldrich and Paul, 2002; Downard et al. 2014), and substantially contributes to the state economy through mineral extraction, commercial brine shrimp harvest, and recreation (Bioeconomics Inc, 2012). However, water diversions and consumptive water uses from rivers that feed Great Salt lake have reduced the lake level by about $3.4 \mathrm{~m}(11 \mathrm{ft})$ and lake area by over $50 \%$ Planned development of water 
supplies in the watershed threaten to lower the lake further and reduce its ecological, cultural and economic value (Wurtsbaugh et al., 2017).

Diking of the shallow system (mean depth $4.5 \mathrm{~m}$ ) and the disproportionate inflow of freshwater into some sections has resulted in four bays with salinities ranging from freshwater to $34 \%$. These salinity regimes, in turn, support very different biological communities, ranging from freshwater fishes and invertebrates of the estuarine-line bays, to brine shrimp, and to only halo-tolerant Archaea, bacteria and some algae in the most saline area.

Lake elevation affects the biology of Great Salt Lake by influencing salinity, nutrients, water temperature, depth, lake habitat area, and exposed lakebed (Barrett and Belovsky 2020). However, to understand Great Salt Lake's water level, it is necessary to understand the hydrology of the lake and upstream water uses that reduce streamflow to the lake and thus alter lake levels. Here we summarize the effects on Great Salt Lake elevation from water development, diversions, and consumptive uses. We include long-term records of streamflows to Great Salt Lake to demonstrate that lake level decline is primarily from water development and consumptive uses. We discuss how Great Salt Lake elevation decline affects biology of Great Salt Lake and its surrounding wetlands. The chapter ends with a discussion of the economic benefits from saline lakes, opportunities to increase Great Salt Lake's elevation, and potential future water development changes along Utah's Wasatch Front and their implications for lake level.

\section{Great Salt Lake Hydrology}

\subsection{Water and Salt Balance}

Streams flow into terminal lakes, but water leaves only through evaporation. In other words, terminal lakes have no stream outlet. Major streams feeding Great Salt Lake include the Bear, Weber, and Jordan Rivers, which drain the west-slope of the Wasatch Range and collectively make up approximately $65 \%$ of the lake's inflows (Fig 1). Direct precipitation to the lake surface accounts for about $33 \%$ of inflows, with the remainder from groundwater and ephemeral West Desert streamflows (Bedford, 2005). Of the 65\% of streamflow contributions to the lake, the Bear River provides 58\%, the Weber River provides 15\%, the Jordan River provides $22 \%$, and the remainder is from small streams. 


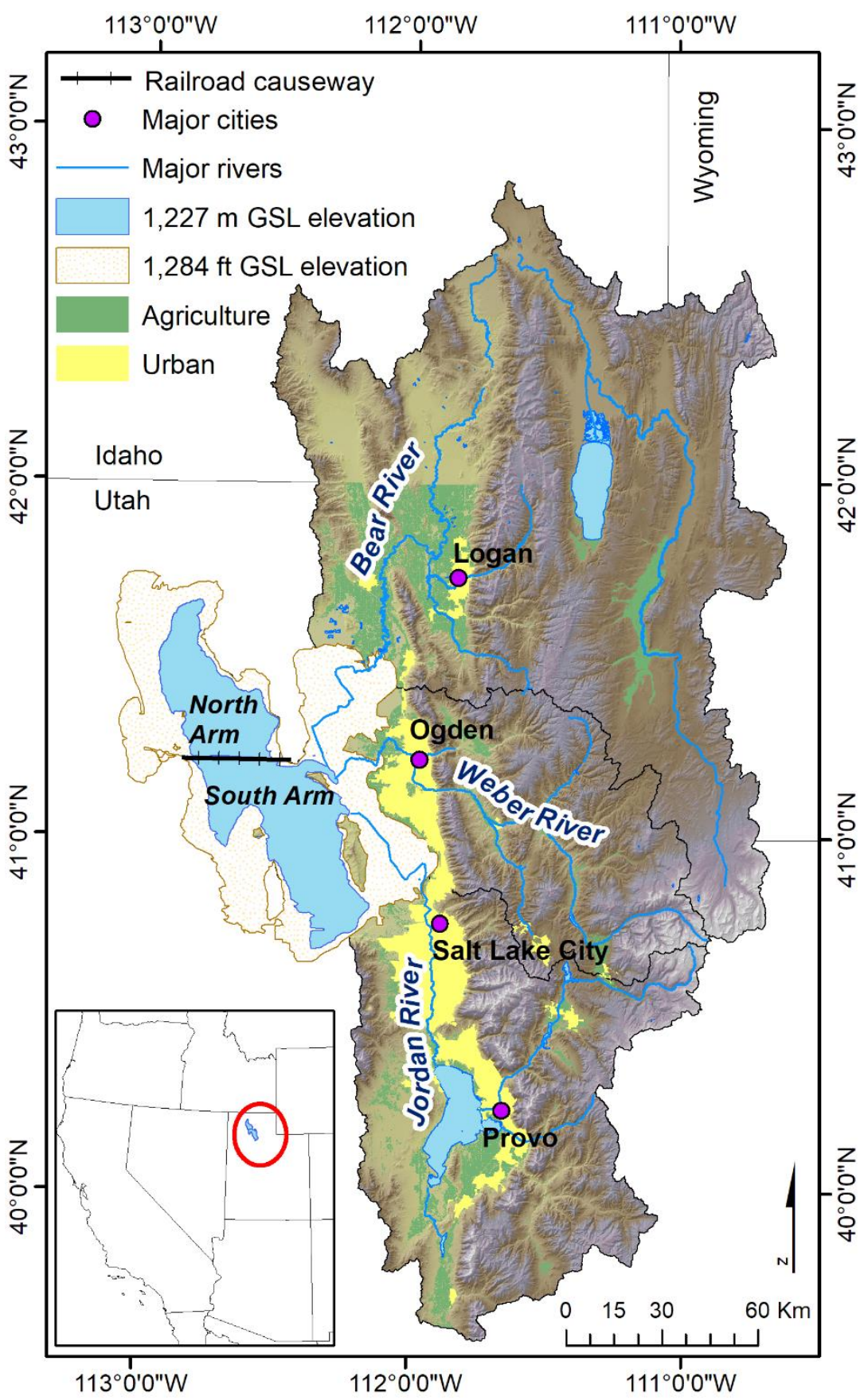

Fig. 1. Great Salt Lake, watersheds, and major rivers, with recent high and low lake elevations

Prior to construction of a railroad causeway that divided the lake in half, the Great Salt Lake was typical of a terminal lake, where dissolved salt concentration varied inversely with lake volume (Loving et al., 2000). In 1959, Great Salt Lake was bisected by Union Pacific Railroad Company's railroad causeway, separating the lake into the north arm (Gunnison Bay) and the south arm (Gilbert Bay) (Fig. 1). The exchange of water and salt between the north and south arms of the lake was forever altered. Additional causeways have further divided the lake, with an automobile causeway to Antelope Island partially separating Farmington Bay from Gilbert Bay, and a salt flume partially restricting interchange between Bear River Bay and Gilbert Bay. 
The Bear, Weber, and Jordan Rivers flow into the south arm (Gilbert Bay), providing freshwater to the south arm of the lake and keeping the surface elevation approximately 0.27 $m$ higher than the north arm (Mohammed and Tarboton, 2012) (Fig 1). Surface inflow to the north arm is nearly all saline water from the south arm. The south arm has lower salinity (typically 8-17\%) and higher biodiversity since it receives nearly all of the streamflow. With little fresh water, but high evaporation, the north arm is often completely saturated with salt ( 27\%) (Johnson et al. In Press).

Some water and salt flows through the railroad causeway at a breach and through the causeway fill. Two rectangular culverts were originally built for boater access between the north and sourth arms of the lake. They provided bi-directional flow between the north and south arms of the lake, but were closed in 2012 and 2013 because they were subsiding into the soft lakebed sediment (White et al., 2015). After three years of negligible water and salt exchange, Union Pacific breached the causeway in 2016, which allowed water exchange between the north and south arms of Great Salt Lake. This brought the elevations of the north and south arms closer to each other. Nevertheless, elevation and salinity differences between the north and south arms remain, with surface flows moving less-salty water from the south arm into the north arm. However, there is a counter-current flow near the lakebed, as very dense, saline water moves from the north to the south arm (Fig. 2). This dense water does not mix readily with the more buoyant water in the south arm, creating a deep brine layer, or monimolimnion. Decomposition of organic matter in this layer makes it anoxic with high concentrations of toxic hydrogen sulfide. Brine shrimp and brine flies cannot survive in this layer. Wind events create turbulence that erodes the deep brine layer, bringing its volume into equilibrium with the inflowing brine from the north. Jones and Wurtsbaugh (2014) roughly estimated that $40 \%$ of the deep brine layer is entrained into the surface layer each year.

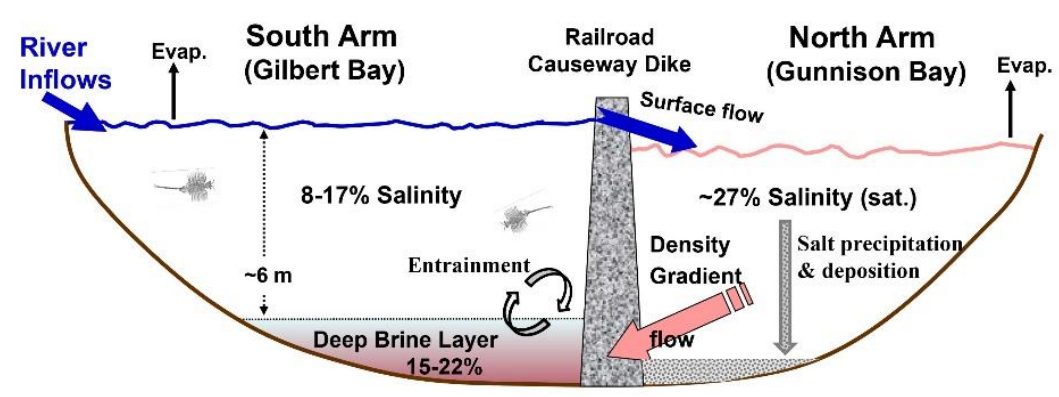

Fig. 2. Bi-directional water and salt transport between the south and north arms of Great Salt Lake. At most lake levels, evaporation brings the north arm to saturation and $\mathrm{NaCl}$ precipitates to the bottom. The deep density flow from the north to the south arm creats a semi-stable deep brine layer at a depth of about $6 \mathrm{~m}$. Wind mixing entrains a portion of this layer into the surface layer of the south arm.

\section{2. $\quad$ Fluctuating Lake Levels Through Time}

Lakes are integrators of droughts, floods, land use, and water use (Schindler, 2009), so the elevation of Great Salt Lake varies through time (Baxter and Butler 2020) (Fig. 3). Recorded lake elevations have ranged by over $6 \mathrm{~m}\left(20^{\prime}\right)$ in the past 170 years, with lower lake elevations approximately halving lake volume and area (Wurtsbaugh et al., 2017) (Fig 1). The shallow bays on the east shore of the lake are impacted even more by water diversions and 
drought. In 2016, when the lake reached its lowest recorded elevation, about $75 \%$ of Bear River Bay and Farmington Bay were dry. These bays have fresher water than the north and south arms, so low water levels greatly reduce important bird habitat and the biodiversity of the lake (Wurtsbaugh et al., 2017).

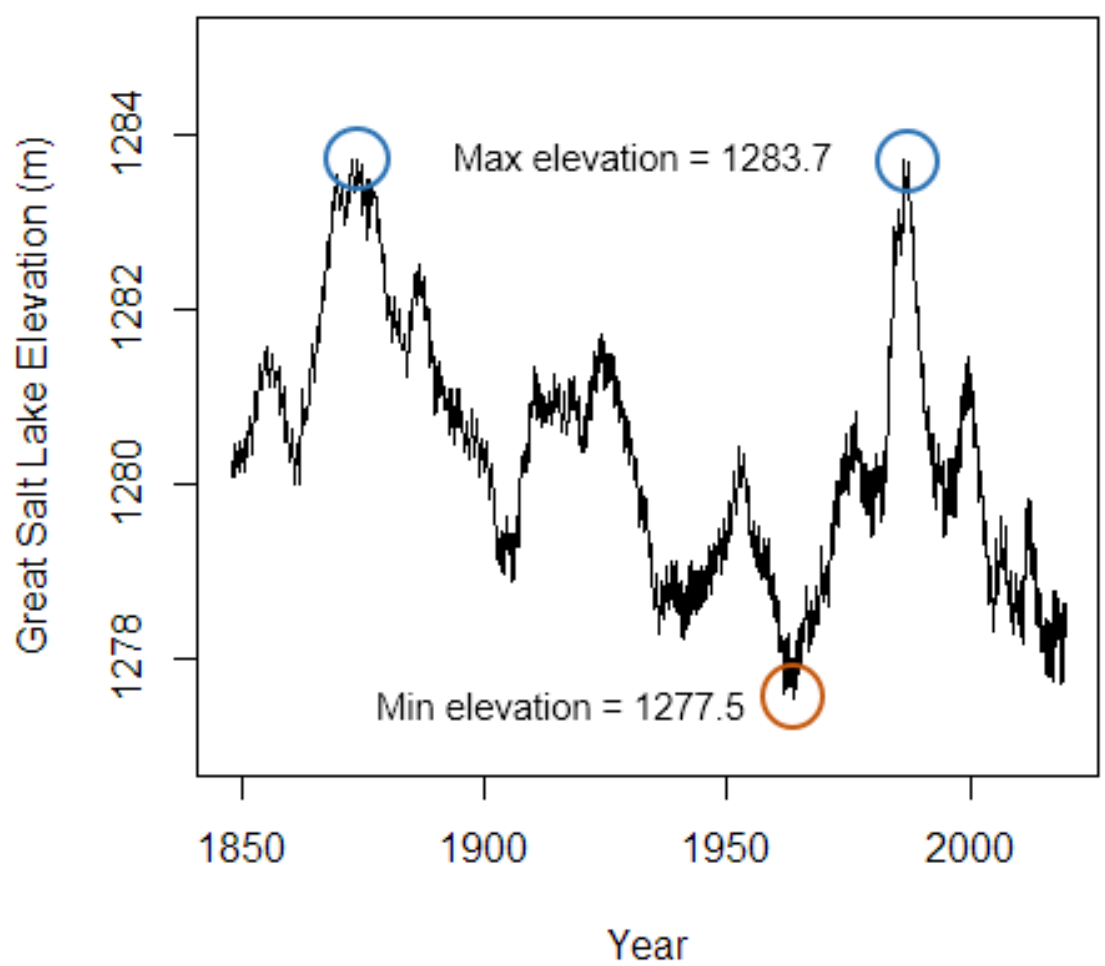

Fig. 3. Great Salt Lake south arm elevation (USGS gage 10010000 - Great Salt Lake at Saltair Boat Harbor). If the north arm is included, the whole lake reached its lowest elevation in 2016 (1277.5 m; $4191.2 \mathrm{ft}$.). South arm elevation was artificially high in 2016 because causeway culverts were closed, allowing for negligible water exchange between the north and south arms.

\subsection{Constant River Flows Through Time}

Despite droughts and pluvials that cause marked changes in lake levels, there has not been a significant long-term streamflow trend in the measured record from watersheds that drain to Great Salt Lake (Fig. 4). In fact, a tree-ring reconstruction of streamflow identified medieval droughts that persisted for decades, but identified no long-term, climate-driven changes to precipitation or streamflows in the past 150 years (DeRose et al., 2015). Gillies et al. (2012) documented an overall slight increase in precipitation in Utah over the 1950-2003 period. Consequently, papers that attribute Great Salt Lake decline to climate change have been debunked (Wine et al., 2019). 


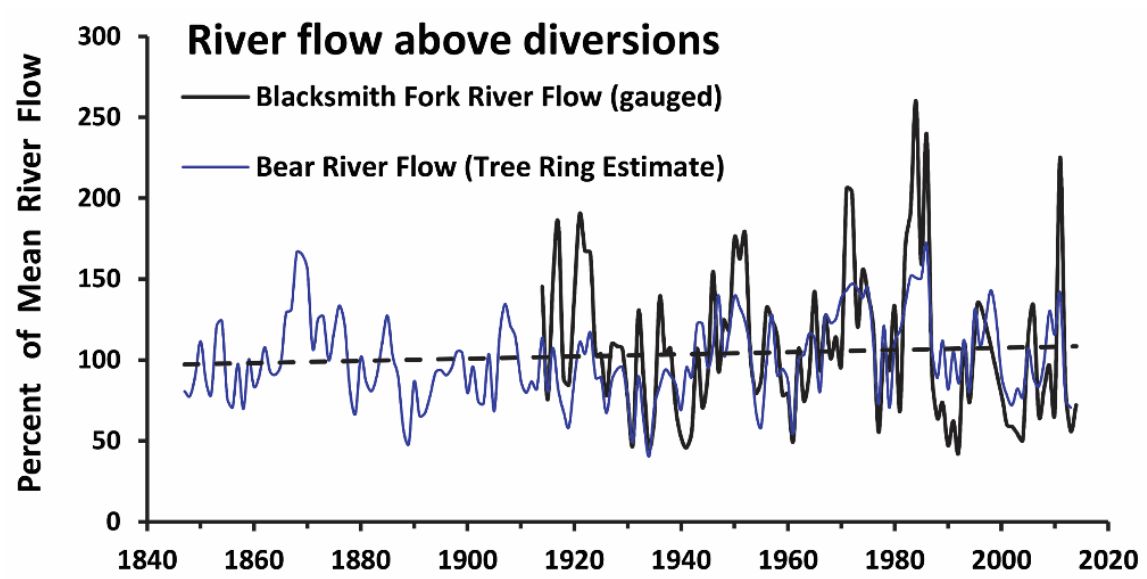

Fig. 4. Estimated streamflows in Great Salt Lake headwater streams upstream of diversions. Flows in the Bear River are based on tree-ring reconstructions (figure reprinted from Wurtsbaugh et al., 2017).

\section{$3 \quad$ Water Development and Consumptive Water Uses}

While Great Salt Lake elevation responds to precipitation changes from droughts and floods, those natural events do not have a persistent trend on lake elevation. On the contrary, Great Salt Lake decline has coincided with water development since pioneers inhabited Salt Lake Valley and the Wasatch Front. Utah had a pronounced dam-building era from the 1930s to the 1990s (Fig. 5), which largely coincided with water development throughout the American West (Reisner, 1993). Today, Utah has an elaborate system of water infrastructure (Fig. 6), including major federal projects like the Central Utah Project that transfers water from the Colorado Basin to the Salt Lake Watershed, the Weber River Project, and the Provo River Project. In addition to reservoirs, pipelines, and canals, pumps and diversion structures take water directly from rivers to irrigate fields.

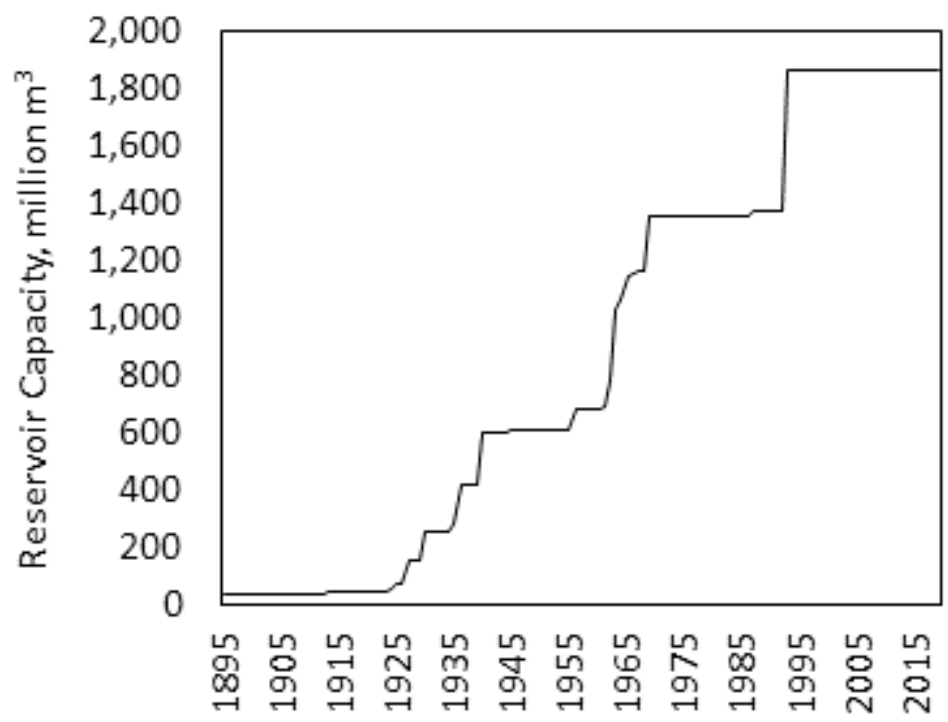

Fig. 5. Cumulative reservoir capacity in the Bear, Weber, and Jordan watersheds, 1895 2019 (data from National Atlas 2006). 


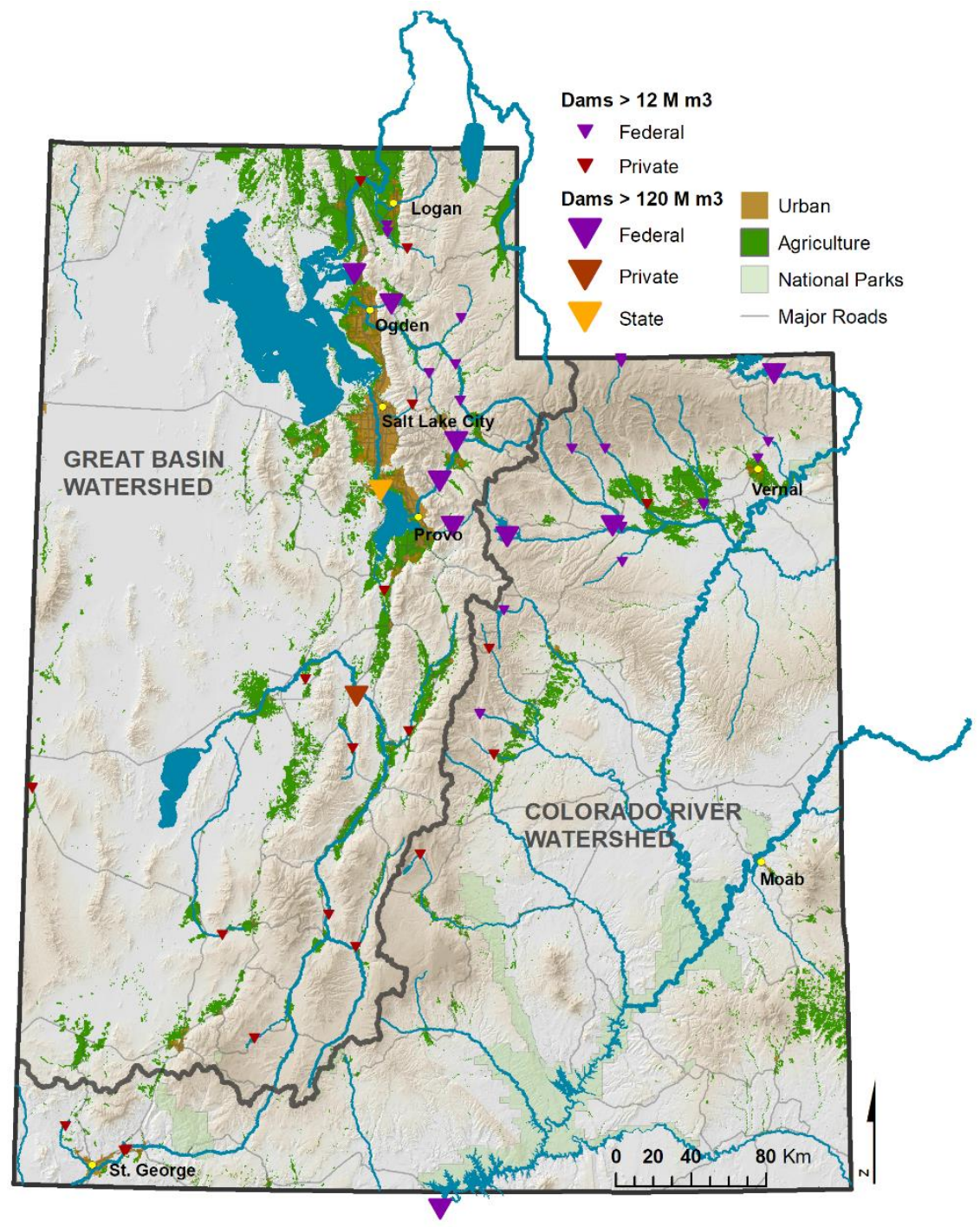

Fig. 6. Utah watersheds and water infrastructure.

Diversions re-direct water away from streams to other uses, usually agricultural or urban uses. However, some diverted water eventually finds its way back to the river downstream and flows to the Great Salt Lake. A small but growing literature has explored water pathways from inefficient irrigated distribution systems (Jensen 2007; Beolens and Vos 2010). This water is not truly 'lost' from the system if it eventually returns to downstream ground and surface water bodies. True consumptive water uses, sometimes called depletions, include water that is consumed, evaporated, or transpirated - water that will not return to Great Salt Lake or the streams that feed it. It is consumptive water uses that are important for considering relationships between water development, water use, and Great Salt Lake elevation decline.

Consumptive water uses were calculated by the Utah Division of Water Resources since 1847, when record-keeping began in this area (Wurtsbaugh et al. 2017). Consumptive water use is split among multiple groups. Irrigated agriculture uses $63 \%$ of water, mineral extraction from Great Salt Lake uses 13\%, cities and industry use 11\%, impounded wetlands use $10 \%$, and evaporation from reservoirs use 3\% of water (Fig 7a) (Wurtsbaugh et al. 2017). Hydrologic modeling has shown that if no diversions or consumptive water extractions had 
occurred, then Great Salt Lake level would be $3.4 \mathrm{~m}$ (11 ft.) higher than it is today (Fig 7b). Overall, water development and consumptive uses of water have reduced streamflows by $39 \%$ (Wurtsbaugh et al., 2017). Consumptive water uses have decreased the area of the lake by $51 \%$ and lake volume by $64 \%$.

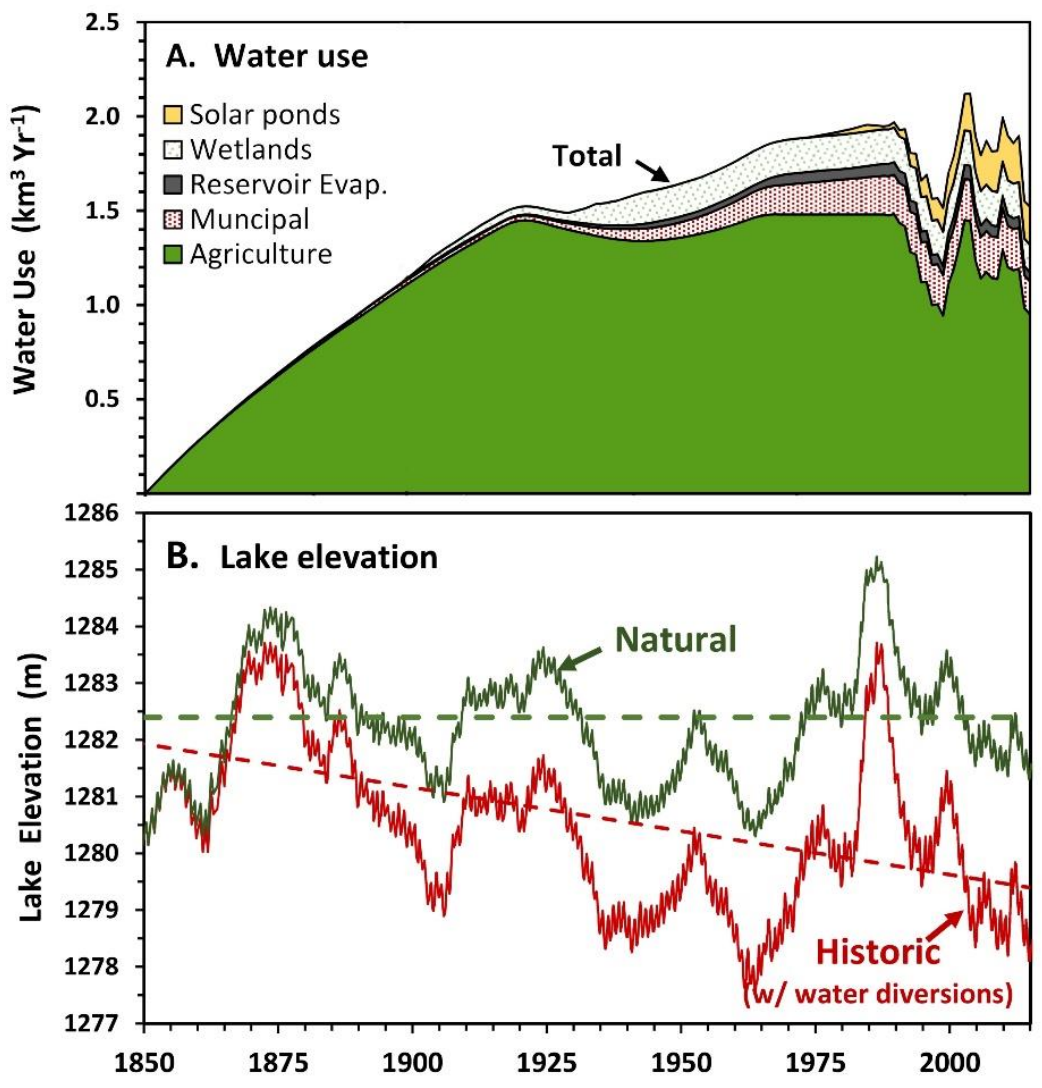

Fig. 7. A) Estimated consumptive water use by user group from 1850 to 2013. B) Measured USGS lake level (red) and modeled lake level had consumptive water uses not occurred (green) (figure modified from Wine et al., 2019).

Variable lake elevations, caused by water depletions, droughts, pluvials and salt extraction, have had a large effect on the salinity of Great Salt Lake. The lake contained approximately 5 billion metric tonnes of salt. During an unusually wet cycle in the mid-1980s, the rising lake level threatened infrastructure encroaching around the shoreline, and a pumping project was undertaken to move water to the desert west of the lake. Along with the water, approximately 0.5 billion tonnes of salt were deposited in the west desert. Despite an investment of $\$ 72$ million, the pumps were only used for about 24 months until June 1989 because the pluvial ended, naturally lowering the lake (White et al. 2015).

The natural wet and dry cycles have a large influence on the salinity. When the lake reached a high level in in 1985, salinities in the south arm decreased to $5.8 \%$. In contrast, when the lake reached it's near-lowest level in 1961, salts were concentrated to $28 \%$.

\section{$4 \quad$ Great Salt Lake Elevation and Biology}

\subsection{Habitat Connectivity with Bays and Wetlands}


Great Salt Lake elevation affects lake and wetland biology (Fig. 8.) Farmington and Bear River Bays, the large bays on the east side of the lake, function as estuaries, with salinity gradients from freshwater near inflows, to hypersaline conditions near their connections with Gilbert Bay. Salinties also vary greatly with droughts and pluvials (Wurtsbaugh et al. 2012). Increasing salinities reduce biodiversity (Hammer 1986), but overall, the bays are highly productive and diverse. Under hypersaline conditions, the invertebrate community is dominated by brine shrimp (Artemia franciscana) and brine flies (Ephydra spp.). As salinities drop below 6-7\%, macroinvertebrates like corixids (water boatmen) can flourish and prey on brine shrimp, and the community becomes dominated by cladocerans, copepods and chironomids in the benthic zone. Near river inflows the bays contain a variety of fish species (Armstrong and Wurtsbaugh In Press 2019). Both bays are important habitat for shorebirds, migratory waterfowl, and other species (Paul and Manning 2002; Wurtsbaugh 2018), and waterfowl hunting is an important component of the $\$ 136$ million spent on recreation at the lake (Bioeconomics 2012; Aldrich and Paul 2002).
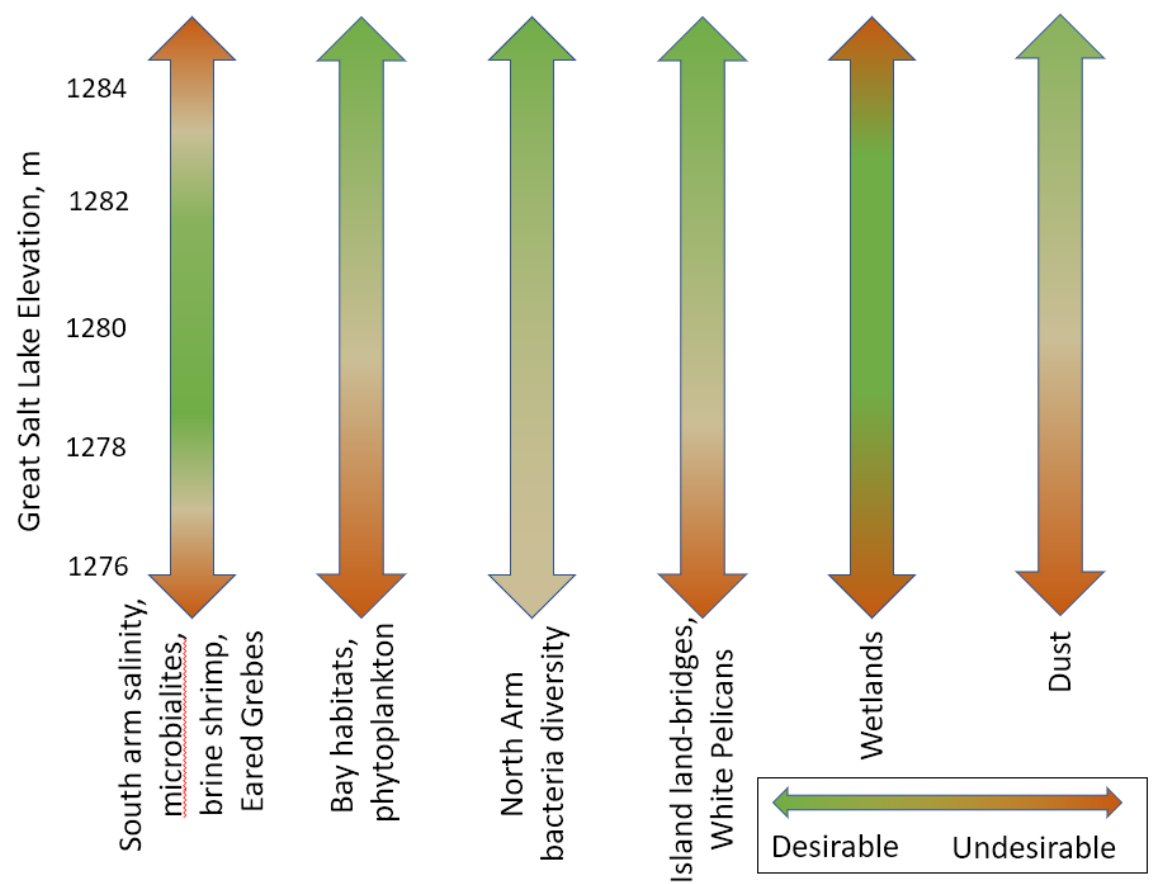

Fig. 8. General relationships between Great Salt Lake elevation and biological parameters (UDNR FFSL, 2013)

Due to water use and drought, over $75 \%$ of Farmington and Bear River Bays lake bottoms have been exposed in recent years, causing vast playas that are a source of dust for the millions of residents along the Wasatch Front (Hahnenberger and Nicoll 2014; Perry et al. In Press 2019). This is especially important for Bear River Bay, where low water levels in 2018 resulted in a $15 \mathrm{~km}$ dry section between it and Gilbert Bay (Fig. 9). 


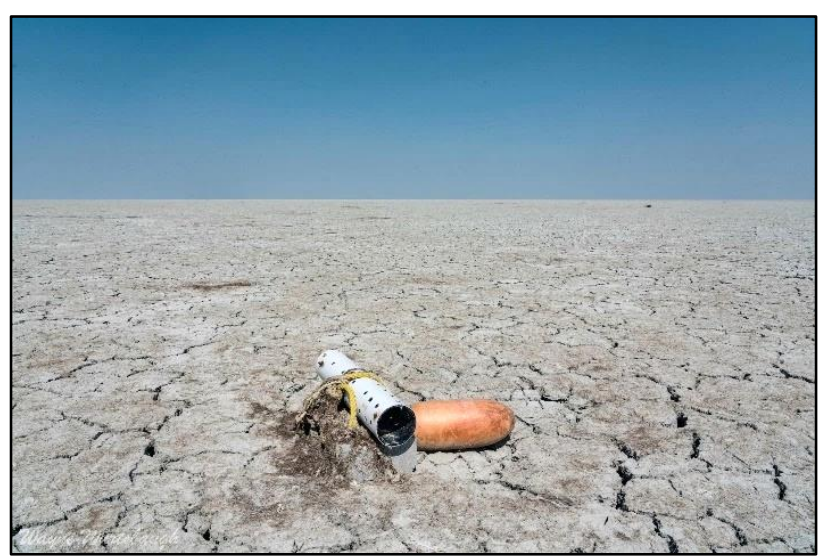

Fig. 9. Abandoned sampling device on the dessicated portion of Bear River Bay caused by water use and drought. Photo: Sept. 2019 when over $150 \mathrm{~km}^{2}$ of the bay was dry.

\subsection{Salinity and Great Salt Lake Biota}

Salinity has an inverse relationship with lake level, so as streamflows decrease, salinity increases (Fig. 10). Microbial mats surround the perimeter of Great Salt Lake and are sensitive to increased salinity. They contribute to the formation of microbialites, which develop when cyanobacteria and periphytic algae reduce the $\mathrm{pH}$ and cause limestone structures to form (Boyd and Lindsay 2020). They are nearly the only solid substrate in the lake, and as such, are important habitat for larval brine flies (Ephydra spp.) that feed on the microbial community (Pace et al., 2016; Wurtsbaugh et al. 2011; Collins 1980). Ongoing research is investigating the salinity thresholds of Great Salt Lake microbial mats and the health of microbiolites.

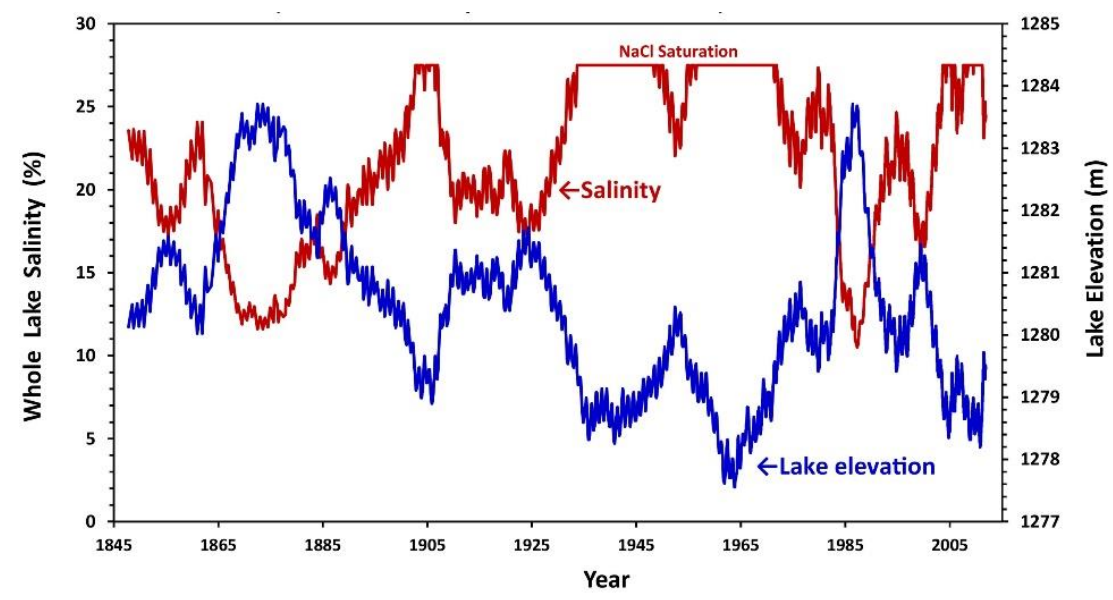

Fig. 10. Estimated whole lake elevations and salinities if Great Salt had not been divided by a railroad causeway. Derived from Null et al. 2013.

When the north arm is saturated, conditions are intolerable for most phytoplankton and macroinvertebrates; however, a diversity of bacteria and Archaea thrive in the hypersaline water (Baxter and Zalar, 2019; Dalmet et al. 2020).

The moderate salinity of the south arm, which averages $13 \%$, supports large populations of macroinvertebrates like brine shrimp (Artemia franciscana) and brine fly (Ephydra cinera). When Great Salt Lake salinity exceeds approximately $12 \%$, brine shrimp become 
physiologically stressed and their production begins to decline, but they are abundant at least up to salinities of 20\% (Barnes and Wurtsbaugh, 2015; Chapt.xxx). Brine flies have higher salinity tolerances, but their growth also declines as salinities climb above $12 \%$. Brine shrimp and brine flies are the most important food resource for birds inhabiting the south arm. Consequently, increasing salinity due to water development is a potential threat to the Great Salt Lake food web. For example, 0.5 to 5.5 million Eared Grebes (Podiceps nigricollis) migrate to Great Salt Lake to feed on brine shrimp and brine flies (Conover 2020; Wurtsbaugh et al. 2011). While doubling their weight at Great Salt Lake, Eared Grebes lose the ability to fly. Thus, if the lake became too saline and brine shrimp production were unable to support the Eared Grebe population, they would be stranded and unable to fly to other lakes with more abundant food sources.

The solid-fill railroad causeway complicates biological effects of salinity (Fig. 2). As mentioned above, streams flow into the south arm, while the north arm typically remains saturated. While unnatural, this maintains a range of salinities in GSL. Under normal conditions salinities in the south arm support high densities of brine shrimp and brine flies, a diversity of phytoplankton, and large populations of Eared Grebes, Phalaropes and other birds that feed on the macroinvertebrates. During exceptionally wet years, such as those in the mid1980 s, salinity in the south arm becomes too low (6\%) to support brine shrimp. However, during these events the salinity in the north arm declines to around $21 \%$ and high densities of brine shrimp may be present (Wurtsbaugh and Berry 1990; Wurtsbaugh 1992). A range of salinities also supports phytoplankton biodiversity, as phytoplankton species vary with salinity though time and by lake depth (Belovsky et al., 2011).

\subsection{Land-Bridges and Bird Rookeries}

Lake islands begin to connect to land when lake levels drop below 4,202 feet. When lake level falls to 4,195 feet, all islands are accessible by land or are separated only by shallow water (Fig. 7) (UDNR FFSL, 2013). When land-bridges form, predators and people can reach bird rookeries. For example, a large population of White Pelicans (Pelecanus erythrorhynchus) nest on Gunnison Island in the north arm of Great Salt Lake. Shallow, wadeable water separates the island from the mainland at about 4,197 feet and a land-bridge forms when lake levels drops below about 4,193 feet (UDNR FFSL, 2013). Great Salt Lake level has consistently been lower than 4,197 feet since 2012 (Fig. 2), threatening one of the largest White Pelican rookeries in North America (Kijowski et al. 2020).

\subsection{Dust}

Water development in the basin has exposed 2,100 $\mathrm{km}^{2}$ of lakebed. Dessicated saline lake beds generate fine dust that harms human health (Griffin and Kellogg 2004) and agriculture (Micklin 2007). Impacts have been well-studied at the Aral Sea in Central Asia where $12,700 \mathrm{~km}^{2}$ of lakebed was exposed due water development for agriculture (Crighton et al. 2011; Micklin 2007; Indoitu et al. 2015). In California's small (285 km²) Owens Lake, dust from the dried lakebed has exceeded US air quality standards for large particulate particles (PM10) (Ramboll Environ US Corporation 2016) and allegedly increased the incidence of lung infections, asthma and other respiratory diseases in the area (Kittle 2000). To mitigate this dust problem the City of Los Angeles will spend \$US 3.6 billion over 25 years (Ramboll Environ US Corporation 2016). The area of exposed Great Salt Lake sediments is over 7 times that of Owens Lake, and the population near the Great Salt Lake is 85 times higher than 
the sparse population near Owens Lake. Consequently, the potential impact of dust for the Wasatch Front is of concern.

Studies on dust emissions from the exposed bed of Great Salt Lake are just beginning. There are no epidemiological studies of the impact of playa dust on human health, but the potential risks are high given results from the dried Aral Sea and Owens Lake. Hahnenberger and Nicoll (2014) found that dust that originated from Great Salt Lake and reached Salt Lake City was important, but other dust sources west of the city were problematic for the city more frequently. A recent study by Perry et al. (In Press 2019) found that only about $9 \%$ of the currently exposed lakebed is likely to produce dust during wind events. Surface crusts and vegetation protect other areas from wind scour. However, Perry found that if all the protective crusts were destroyed by rains, natural erosion and human activities, $22 \%$ or $460 \mathrm{~km}^{2}$, of the exposed lakebed would produce dust. Exposed lakebed area would increase or decrease by $23-46 \%$ for each meter change in lake level, depending on bay. Consequently, any additional water development in the basin will increase the potential for dust production.

Perry also analyzed lakebed sediments for heavy metals and found that nine elements exceeded the Residential Regional Screening Levels established by the U.S. Environmental Protection Agency (EPA 2019). Four of these elements (arsenic, lanthanum, lithium, and zirconium) had some values that exceeded the EPA's Industrial Screening Levels. However, mercury concentrations were well below either screening level. These metals will not necessarily cause a health risk depending on exposure to the dust. Regardless, site-specific exposure assessments should be done for the most problematic metals (Perry et al. In Press 2019).

\section{Potential Solutions to Reduce Consumptive Water Uses and Stabilize Great Salt Lake Level}

Saline lakes are valuable. In 2012, Great Salt Lake generated approximately $\$ 1.3$ billion of Utah's gross domestic product (Bioeconomics Inc, 2012), or about $\$ 1.48$ billion in 2019 dollars, assuming an average inflation rate of $1.62 \%$. Of that amount, about $85.5 \%$ is generated from mineral extraction, $10.3 \%$ from recreation, and $4.3 \%$ from the brine shrimp industry (Bioeconomics Inc, 2012). In addition to the quantifiable economic value, Great Salt Lake is immensely valuable ecologically for the millions of birds that utilize the ecosystem. Conversely, the vast lakebed, when dried, becomes a source of dust that can cause costly health problems for millions of residents in greater metropolitan Salt Lake City (Perry et al. In Press 2019).

\subsection{Mechanisms to Preserve Saline Lakes Globally}

Elevations to maintain desired ecosystem services of Great Salt Lake have been estimated (UDNR FFSL, 2013); however, minimum streamflow requirements or mechanisms to maintain lake elevation have not been developed. A wide array of strategies have been implemented to preserve other saline lakes (Table 1). For example, litigation-driven water conservation at Mono Lake (Hart 1996), water purchases from willing sellers at Walker Lake (Elmore et al. 2016), and an inter-basin water transfer at the Dead Sea (Gavrieli et al. 2011) are varied mechanisms to maintain lake elevations. For other saline lakes, substantial changes have been tolerated to preserve a remnant of the lake or to maintain select ecosystem services. Diking has reduced Aral Sea area to about 5\% the size of the original lake, allowing 
salinities to remain low enough to support a fish community (Micklin, 2016). Shallow flooding, managed wetlands, and gravel mitigate for airborne dust at Owens dry lakebed (Gutrich et al., 2016), while shallow flooding, ponds, and berms are used at Salton Sea to maintain some minimal habitat and reduce airborne dust (California Natural Resources Agency, 2015).

Table 1. Mechanisms to restore saline lakes

\begin{tabular}{|lll|}
\hline $\begin{array}{l}\text { Restoration } \\
\text { Goal }\end{array}$ & Mechanism & Lake (Location) \\
\hline $\begin{array}{l}\text { Increase lake } \\
\text { elevation }\end{array}$ & $\begin{array}{l}\text { Litigation and water con- } \\
\text { Servation } \\
\text { Environmental water pur- } \\
\text { chases }\end{array}$ & $\begin{array}{l}\text { Mono Lake } \\
\text { (California, USA) } \\
\text { Walker Lake } \\
\text { (Nevada, USA) }\end{array}$ \\
\hline $\begin{array}{l}\text { Inter-basin water transfer } \\
\text { area }\end{array}$ & $\begin{array}{l}\text { Dead Sea } \\
\text { (Jordan, Israel, and } \\
\text { Palestine) }\end{array}$ \\
\hline $\begin{array}{l}\text { Mitigate dust } \\
\text { and preserve } \\
\text { habitat }\end{array}$ & $\begin{array}{l}\text { Shallow flooding, managed } \\
\text { wetlands, gravel cover }\end{array}$ & $\begin{array}{l}\text { Aral Sea } \\
\text { (Kazakhstan and } \\
\text { Uzbekistan) }\end{array}$ \\
\hline
\end{tabular}

\subsection{Opportunities to Preserve Great Salt Lake Level}

Utah has over 3 million people with about $80 \%$ of the population living in the metropolitan Wasatch Front (Fig 1). Utahns have the second highest per capita water use of the United States at 1109 liters per person per day (293 gallons per person per day) (Office of the Legislative Auditor General, 2015). Water use far exceeds that of other arid regions in the world (Fig. 11). Permanently implementing water cutbacks to urban and agricultural water users could cost between $\$ 14-96$ million ( $\$ 5$ to $\$ 32$ per person), depending on upper and lower cost estimates (Edwards and Null, 2019). However, with a water conservation market between water users and watersheds, costs drop substantially to $\$ 6-48$ million ( $\$ 2$ to $\$ 16$ per person). Water conservation measures are varied and could include low water use toilets, showers, and washing machines, urban and agricultural water scheduling, turf conversion, rain barrels, and more (Edwards et al., 2017). These costs are inexpensive, although opportunity costs given by lost benefits of consumptive water uses could also generate supply curves for water to Great Salt Lake (Genova et al. 2019). Proposed state legislation to enable water banking in Utah may facilitate water trading in the future. Water banking allows farmers or other water users to forego their water use without forfeiting water rights. It enables water trading between willing water sellers and buyers and may have the potential to facilitate dedicated streamflows to Great Salt Lake. 


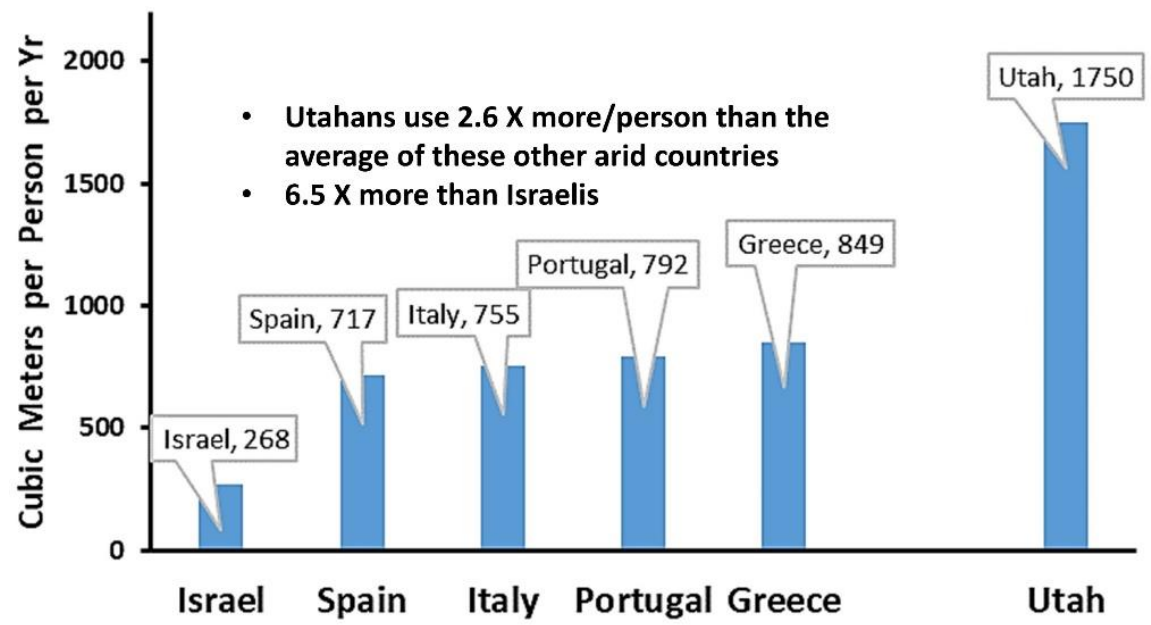

Fig. 11. Per capita water use in Utah compared to that other arid regions. Data derived from Pacific Institute (2013).

Some urban water districts are considering implementing green infrastructure such as rain barrels, retention ponds, permeable pavement, or bioswales to recharge groundwater and baseflows (Prudencio and Null, 2018). However, this approach is unlikely to offset anticipated drying from climate change (York et al. 2015). A menu of potential strategies to provide water to Great Salt Lake has been developed, including water conservation, groundwater management, reducing vegetation around the lake, applying the Public Trust Doctrine used to preserve Mono Lake, removing dams, enlarging dams, and inter-basin water transfers (SWCA Environmental Consultants, 2017; Clyde 2016). The list is a starting point to encourage discussion and strategies have yet to be prioritized or thoroughly evaluated.

\subsection{Future Changes}

Consumptive water uses have caused Great Salt Lake elevation to decline by $3.4 \mathrm{~m}$ (11 ft.) since pioneers colonized Salt Lake Valley (Wurtsbaugh et al., 2017). Utah's population is anticipated to double by 2060 and $80 \%$ of the population lives along the Wasatch Front in the Great Salt Lake watershed. This suggests that water development and diversions to urban and agricultural users will change and evolve in coming decades.

In fact, considerable water development of the Bear River for urban and agricultural use is being considered. The Bear River Compact between the States of Utah, Idaho and Wyoming envisions the development of 1,600 million $\mathrm{m}^{3}$ (1.3 million af) of water. If all of this water is developed, it would lower the lake more than $1.6 \mathrm{~m}(5.4 \mathrm{ft}$.) beyond what has already occurred. This would raise salinity to over $22 \%$ and brine shrimp populations would be greatly diminished. Idaho and Wyoming have not yet funded projects to develop their water. But in 1991, the Utah legislature passed the Bear River Development Act, which directs the state to develop 270 million $\mathrm{m}^{3}$ (220,000 af) of surface water in the Bear River and its tributaries through construction of reservoirs and associated facilities. Hydrologic modeling suggests that Utah's Bear River Development Project, which is estimated to cost $\$ 1.5$ billion, would lower Great Salt Lake by an additional $20 \mathrm{~cm}$ (8 in) (Wurtsbaugh et al., 2017). 
Utah has not fully developed its share of water from the Colorado River according to the Colorado River Compact and transfers of water have been proposed (SWCA Environmental Consultants 2017). Cost estimates are unavailable, although the proposed Lake Powell Pipeline to southwest Utah is estimated to cost \$1.1 to \$1.8 billion (LPP 2019). While increasing water supply appears to be a costly, but possible, solution to maintain Great Salt Lake elevation, previous research has shown that interbasin transfers temporarily mask water supply problems, but do not address underlying problems of unsustainable water use and development (AghaKouchak et al., 2015). In other words, interbasin water transfers have been shown to be a temporary fix that backfires in the long-run (Gohari et al., 2013).

\section{Concluding Remarks}

Population growth and development in a semi-arid climate elicits questions like: How will water development and operations affect flows to the Great Salt Lake and surrounding wetland habitats? What is the role of water conservation, water markets, stormwater management, water infrastructure, and coordinated management of existing facilities to simultaneously maintain human benefits and preserve ecosystems?

Restoration of other terminal lakes has shown that it is more costly to restore lakes and the ecosystem services they provide than to preserve them from the outset. For instance, Libecap (2009) estimated that the costs of litigating the out-of-basin water transfers for California's Mono Lake over 20 years likely exceeded the actual value of the water. Mitigating for airborne dust in Owens dry lakebed has already cost over $\$ 1$ billion, and that does not include restoration of the lake (Gutrich et al., 2016). It is estimated to cost $\$ 3.6$ billion over 25 years (Ramboll Environ US Corporation 2016). Even securing water for terminal lakes is costly. As of 2016, $\$ 57$ million had been spent purchasing about 20,000 af of water from willing sellers to increase the elevation of Walker Lake (Null et al. 2017).

Large declines in lake level and salinity threaten the unique biology of Great Salt Lake. Quantifying water diversions from rivers that feed Great Salt Lake, consumptive water uses, and total streamflow that reaches Great Salt Lake will allow Utahns to make defensible decisions to manage water resources and GSL biology for long term ecological and economic benefit. Utah has potential opportunities and multiple alternatives to improve water management and maintain water supply to Great Salt Lake.

\section{ACKNOWLEDGEMENTS}

This work was partially supported from a National Science Foundation CAREER Award (\#1653452). Any opinions, findings, and conclusions or recommendations expressed in this chapter are those of the authors and do not necessarily reflect the views of the National Science Foundation. Craig Miller of the Utah Department of Water Resources shared data and guided the development of the hydrological depletion model for Great Salt Lake. David Tarboton shared hypsographic data allowing us to predict exposed lake bed area. Peter Wilcock, Justin DeRose, Maura Hahnenberger, and Jonnie Moore participated in the development of a earlier paper documenting the decline of Great Salt Lake. 


\section{REFERENCES}

AghaKouchak, A., Norouzi, H., Madani, K., Mirchi, A., Azarderakhsh, M., Nazemi, A., Nasrollahi, N., Farahmand, A., Mehran, A., Hasanzadeh, E. (2015) Aral Sea syndrome desiccates Lake Urmia: call for action, Journal of Great Lakes Research 41(1), pp. 307 311.

Aldrich, T. W. and Paul, D. S. (2002) Avian Ecology Of Great Salt Lake. In: Gwynn JW (ed) In Great Salt Lake: An Overview Of Change. Utah Department of Natural Resources, Salt Lake City, Salt Lake City, pp 343-374.

Armstrong T, Wurtsbaugh WA (In Press 2019) Impacts of eutrophication on benthic invertebrates \& fish prey of birds in Farmington and Bear River Bays of Great Salt Lake. Final Report to the Utah Division of Forestry, Fire \& State Lands, Salt Lake City.

Barnes, B. D. and Wurtsbaugh, W. A. (2015) The effects of salinity on plankton and benthic communities in the Great Salt Lake, Utah, USA: a microcosm experiment, Canadian Journal of Fisheries and Aquatic Sciences, 72(6), pp. 807-817. doi: 10.1139/cjfas-20140396.

Barrett, K.L. and G. Belovsky. (2020) Invertebrates and phytoplankton: a delicate balance across salinity gradients. In Baxter, B.K and Butler, J.K., Eds. Great Salt Lake Biology: A Terminal Lake in a Time of Change. Springer, Netherlands.

Baxter, B.K. and Butler, J.K. (2020) Climate Change and Great Salt Lake. In Baxter, B.K and Butler, J.K., Eds. Great Salt Lake Biology: A Terminal Lake in a Time of Change. Springer, Netherlands.

Baxter, B. K. and Zalar, P. (2019) The Extremophiles of great salt lake: complex microbiology in a dynamic hypersaline ecosystem, in Model Ecosystems in Extreme Environments. Elsevier, pp. 57-99.

Bedford, D. (2005) Utah's Great Salt Lake: A complex environmental-societal system, Geographical Review. Wiley Online Library, 95(1), pp. 73-96.

Belovsky, G. E., Stephens, D., Perschon, C., Birdsey, P., Paul, D., Naftz, D., Baskin, R., Larson, C., Mellison, C., Luft, J., Mosley, R., Mahon, H., Van Leeuwen, J., Allen, D.V. (2011) The Great Salt Lake Ecosystem (Utah, USA): long term data and a structural equation approach, Ecosphere 2(3), pp. 1-40.

Bioeconomics Inc. (2012) Economic significance of the Great Salt Lake to the State of Utah. Great Salt Lake Advisory Council. Salt Lake City, Utah.

Boelens, R., and J. Vos (2010) The danger of naturalizing water policy concepts: Water productivity and efficiency discourses from field irrigation to virtual water trade, Agr. Water Management, 108, 16-26, doi:10.1016/j.agwat.2011.06.013.

California Natural Resources Agency (2015) Salton Sea Species Conservatin Habitat Monitoring and Adaptive Management Plan. Prepared by Cardno Inc. and Environmental Science Associates. 64 pages. Available online: https://water.ca.gov/-/media/DWRWebsite/Web-Pages/Programs/Engineering-And-Construction/Files/Design-Build/SaltonSea-Reports/07_Monitoring_Adaptive_Mgmt_Plan.pdf.

Clyde S.E. (2016) Water rights for Great Salt Lake: is it the impossible dream? p 1-29, Utah Water Law, CLE International, Salt Lake City, Utah http://wwwclydesnowcom/images/Articles--Great-Salt-Lake-Paper-2016-01090010xB165Bpdf.

Collins N. (1980) Population ecology of Ephydra cinerea Jones (Diptera, Ephydridae), the only benthic metazoan of the Great Salt Lake, USA. Hydrobiologia 68:99-112.

Conover, M. R. (2020) Is Great Salt Lake the only think keeping Eared Grebes from going extinct? In Baxter, B.K and Butler, J.K., Eds. Great Salt Lake Biology: A Terminal Lake in a Time of Change. Springer, Netherlands. 
Crighton E.J., Barwin L., Small I., Upshur R. (2011) What have we learned? A review of the literature on children's health and the environment in the Aral Sea area. Int J Public Health 56:125-138. doi:10.1007/s00038-010-0201-0.

DeRose, R. J., Bekker, M.F., Wang, S-Y., Buckley, B.M., Kjelgren, R.K., Bardsley, T. Rittenour, T.M., Allen, E.B. (2015) A millennium-length reconstruction of Bear River stream flow, Utah, Journal of Hydrology 529, pp. 524-534.

Downard, R., Endter-Wada, J. and Kettenring, K. (2014) Adaptive wetland management in an uncertain and changing arid environment, Ecology \& Society, 19(2).

Edwards, E.C., Bosworth, R.C., Adams, P., Baji, V., Burrows, A., Gerdes, C., Jones, M. (2017) Economic Insight from Utah's Water Efficiency Supply Curve, Water 9(3), p. 214.

Edwards, E.C. and Null, S. E. (2019) The cost of addressing saline lake level decline and the potential for water conservation markets, Science of The Total Environment 651(1), pp. 435-442.

Elmore, L.R., Null, S.E. and Mouzon, N.R. (2016) Effects of environmental water transfers on stream temperatures, River Research and Applications 32(7), pp. 1415-1427.

EPA (2019) Regional Screening Levels (RSLs)--Generic Tables. https://www.epa.gov/risk/regional-screening-levels-rsls-generic-tables.

Gavrieli, I., Lensky, N.G., Abelson, M., Ganor, J., Oren, A., Brenner, S., Shahar, H. (2011) Red Sea to Dead Sea water conveyance (RSDSC) study: Dead Sea research team, Rep. GSI/10/2011.

Génova, P.A., S.E. Null, Olivares,M.A (2019) An economic-engineering method to allocate water between instream and off-stream uses. Journal of Water Resources Planning and Management 145(3): 04018101. doi: 10.1061/(ASCE)WR.1943-5452.0001026.

Gillies R.R., Wang S-Y., Booth M.R. (2012) Observational and Synoptic Analyses of the Winter Precipitation Regime Change over Utah. J Clim 25:4679-4698.

Griffin D.W., Kellogg C.A. (2004) Dust storms and their impact on ocean and human health. EcoHealth 1:284-295.

Gohari, A., Eslamian, S., Mirchi, A., Abedi-Koupaei, J., Bavani, A.M., Madani, K. (2013) Water transfer as a solution to water shortage: a fix that can backfire, Journal of Hydrology 491, pp. 23-39.

Gutrich, J.J., Gigliello, K., Gardner, K.V., Elmore, A.J. (2016) Economic returns of groundwater management sustaining an ecosystem service of dust suppression by alkali meadow in Owens Valley, California, Ecological Economics 121, pp. 1-11.

Hahnenberger M., Nicoll K. (2014) Geomorphic and land cover identification of dust sources in the eastern Great Basin of Utah, U.S.A. Geomo 204:657-672. doi:https://doi.org/10.1016/j.geomorph.2013.09.013.

Hammer U.T. (1986) Saline lake ecosystems of the World. Dr W. Junk, Dordrecht, Dordrecht.

Hart, J. (1996) Storm over Mono: The Mono Lake battle and the California water future. Univ of California Press. ISBN: 0520203682.

Indoitu R., Kozhoridze G., Batyrbaeva M., Vitkovskaya I., Orlovsky N., Blumberg D., Orlovsky L. (2015) Dust emission and environmental changes in the dried bottom of the Aral Sea. Aeolian Res 17:101-115. doi:10.1016/j.aeolia.2015.02.004.

Jensen, M.E. (2007) Beyond irrigation efficiency. Irrigation Science 25: 233-245. doi:10.1007/s00271-007-0060-5.

Johnson WP, Wurtsbaugh WA, Belovsky GE, Baxter BK, Black F, Angeroth C, Jewell P, Yang S (In Press) Geochemistry of Great Salt Lake. Encyclopedia of Water: Science, Technology, and Society 2019. 
Jones E.F., Wurtsbaugh, W.A. (2014) The Great Salt Lake's monimolimnion and its importance for mercury bioaccumulation in brine shrimp (Artemia franciscana). Limnol Oceanogr 59:141-155.

Kijowski, A.M., Neill, J., Wickline, A., Swift, J. Butler, J.K., Kimberly, D.A., Van Leeuwen, J., Luft, J., Stone, K. (2020) American White Pelicans of Gunnison Island, Great Salt Lake, Utah. In Baxter, B.K and Butler, J.K., Eds. Great Salt Lake Biology: A Terminal Lake in a Time of Change. Springer, Netherlands.

Kittle S. (2000) Survey of reported health effects of Owens Lake particulate matter. Great Basin Unified Air Pollution Control District, Bishop, California. 10 p.; http://www.gbuapcd.org/Information/SurveyofReportedHealthEffectsofOwensLakeParticulateMatter.pdf.

Libecap, G.D. (2009) The tragedy of the commons: property rights and markets as solutions to resource and environmental problems, Australian Journal of Agricultural and Resource Economics 53(1), pp. 129-144.

Loving, B.L., Miller, C.W. and Waddell, K.M. (2000) Water and salt balance of Great Salt Lake, Utah, and simulation of water and salt movement through the causeway, 1987-98, Water-Resources Investigations Report. U.S. Geological Survey.

LPP (Lake Powell Pipeline) (2019) Washington County's Repayment Options for the Lake Powell Pipeline fact sheet. Available online: https://lpputah.org/wp-content/uploads/2019/01/LLPFactSheet-Repayment-Options-012819.pdf.

Micklin P. (2007) The Aral Sea disaster. AREPS 35:47-72. doi:10.1146/annurev.earth.35.031306.140120.

Micklin, P. (2016) The future Aral Sea: hope and despair, Environmental Earth Sciences 75(9), p. 844.

Mohammed, I.N. and Tarboton, D.G. (2012) An examination of the sensitivity of the Great Salt Lake to changes in inputs, Water Resources Research 48(11). doi: 10.1029/2012WR011908.

Null, S.E., Mouzon, N.R. and Elmore, L.R. (2017) Dissolved Oxygen, Stream Temperature, and Fish Habitat Response to Environmental Water Purchases, Journal of Environmental Management 197(15), 559-570.

Null S.E., Wurtsbaugh W.A., Miller C. (2013) Can the causeway in the Great Salt Lake be used to manage salinity. 2 p. Friends of the Great Salt Lake Newsletter Vol. 19(1). http://works.bepress.com/wayne_wurtsbaugh/143/.

Office of the Legislative Auditor General (2015) A Performance Audit of Projections of Utah's Water Needs. Report to the Utah Legislature Number 2015-01. 82 pages. Available at: https://water.utah.gov/1 AuditProjectionsUtahWater Needs.pdf.

Pace, A., Bourillot, R., Bouton, A., Vennin, E., Galaup, S., Bundeleva, I., Patrier, P., Dupraz, C., Thomazo, C., Sansjofre, P. and Yokoyama, Y. (2016) Microbial and diagenetic steps leading to the mineralisation of Great Salt Lake microbialites. Scientific reports 6, p.31495.

Pacific Institute (2013) The World's water, Vol. 7. http://worldwater.org/wp-content/uploads/2013/07/ww8-table2.pdf.

Paul D.S., Manning A.E. (2002) Great Salt Lake Waterbird Survey Five-Year Report (19972001). Publication Number 08-38. Utah Division of Wildlife Resources, Salt Lake City, Utah, USA.

Perry K.D., Crosman E.T., Hoch S.W. (In Press 2019) Results of the Great Salt Lake dust plume study (2016-2018). Final Report to Utah Forestry, Fire and State Lands, Salt Lake City, UT. 319 p. 
Prudencio, L. and Null, S.E. (2018) Stormwater management and ecosystem services: a review, Environmental Research Letters 13(3). doi: 10.1088/1748-9326/aaa81a.

Ramboll Environ US Corporation (2016) Great Basin Unified Air Pollution Control District: 2016 Owens Valley Planning Area PM10 State implementation plan. Great Basin Unified Air Pollution Control District, Bishop, California. 1494 p.

http://www.gbuapcd.org/Air\%20Quality\%20Plans/OVPA_SIP_2016/2016_SIP_FINAL_20160413.pdf.

Reisner, M. (1993) Cadillac desert: the American West and its disappearing water. New York, NY: Penguin Books.

Schindler, D.W. (2009) Lakes as sentinels and integrators for the effects of climate change on watersheds, airsheds, and landscapes, Limnology and Oceanography 54(6, part2): 23492358.

SWCA Environmental Consultants (2017) Water for Great Salt Lake. Prepared for Great Salt Lake Advisory Council. Salt Lake City, UT. 54 pages.

UDNR FFSL (Utah Department of Natural Resources Division of Forestry, Fire and State Lands) (2013) Final Great Salt Lake Comprehensive Management Plan and Record of Decision. Prepared by SWCA Environmental Consultants. Salt Lake City, UT. 391 pages. Available at: https://ffsl.utah.gov/wp-content/uploads/OnlineGSL-CMPandRODMarch2013.pdf.

White, J.S., Null, S.E. and Tarboton, D.G. (2015) How Do Changes to the Railroad Causeway in Utah's Great Salt Lake Affect Water and Salt Flow?, PloS One. 10(12), p. e0144111.

Wine, M.L., Null, S.E., DeRose, J.R., Wurtsbaugh, W.A. (2019) Climatization-Negligent Attribution of Great Salt Lake Desiccation: A Comment on Meng (2019), Climate 7(5), p. 67.

Wurtsbaugh W.A. (1992) Food web modifications by an invertebrate predator in the Great Salt Lake (USA). Oecologia 89:168-175.

Wurtsbaugh W.A. (2012) Paleolimnological analysis of the history of metals contamination in the Great Salt Lake, Utah, USA. Final report to the Utah Division of Water Quality, Salt Lake City, Utah. 44 p. http://digitalcommons.usu.edu/wats_facpub/556/.

Wurtsbaugh W.A. (2018) Effects of eutrophication on birds in three bays of Great Salt Lake: A comparative analysis with Utah DWR Waterbird Survey Data. Final Report. Utah Division of Forestry, Fire and State Lands. https://digitalcommons.usu.edu/wats_facpub/1012/

Wurtsbaugh, W.A. and Berry, T.S. (1990) Cascading Effects of Decreased Salinity on the Plankton Chemistry, and Physics of the Great Salt Lake (Utah), Canadian Journal of Fisheries and Aquatic Sciences 47(1), pp. 100-109. doi: 10.1139/f90-010.

Wurtsbaugh W.A., Gardberg J, Izdepski C (2011) Biostrome communities and mercury and selenium bioaccumulation in the Great Salt Lake (Utah, USA). Sci Total Environ 409:4425-4434. doi:10.1016/j.scitotenv.2011.07.027

Wurtsbaugh W.A., Marcarelli A.M., Boyer G.L. (2012) Eutrophication and metal concentrations in three bays of the Great Salt Lake (USA). 2009 Final report to the Utah Division of Water Quality, Salt Lake City, Utah. 70 p. http://digitalcommons.usu.edu/cgi/viewcontent.cgi? article $=1548 \&$ context $=$ wats_facpub.

Wurtsbaugh, W.A., Miller, C., Null, S.E., DeRose, R.J., Wilcock, P., Hahnenberger, M., Howe, F., Moore, J. (2017) Decline of the world's saline lakes, Nature Geoscience 10: 816-821. 
York, C., Goharian, E. and Burian, S.J. (2015) Impacts of large-scale stormwater green infrastructure implementation and climate variability on receiving water response in the Salt Lake City area, American Journal of Environmental Sciences 11(4), p. 278. 